\title{
PRVI NALAZ HRASTOVE MREŽASTE STJENICE (Corythucha arcuata) U BOSNI I HERCEGOVINI
}

\author{
FIRST RECORD OF OAK LACE BUG (Corythucha arcuata) \\ IN BOSNIA AND HERZEGOVINA
}

\author{
Mirza DAUTBAŠIĆ ${ }^{1}$, Kenan ZAHIROVIĆ ${ }^{2}$, Osman Mujezinović1, Josip MARGALETIĆ3
}

\begin{abstract}
Sažetak
U ovome radu opisan je prvi nalaz hrastove mrežaste stjenice (Corythuca arcuata) na području centralne Bosne, na dva lokaliteta. Kako je ovo prvi nalaz ove vrste na području Bosne i Hercegovine, potrebna su dodatna istraživanja biologije i štetnosti ovog insekta. Budući da je ovo strana i potencijalno invazivna vrsta, može se očekivati njeno širenje po teritoriji čitave Bosne i Hercegovine.
\end{abstract}

KLJUČNE RIJEČl: hrast kitnjak, hrastova mrežasta stjenica, strana vrsta, centralna Bosna, zdravstveno stanje šuma.

\section{UVOD}

\section{INTRODUCTION}

Šume hrasta kitnjaka u Bosni i Hercegovini zauzimaju površinu od oko 300.000 ha i najrasprostranjenije su u Bosanskoj Posavini, u donjim tokovima rijeke Une, Vrbasa, Bosne i Drine (Matić i dr., 1971). Hrastove šume na ovim prostorima su destabilizirane djelovanjima raznih abiotičkih i biotičkih čimbenika (suše, mrazovi, sustav gazdovanja, način gospodarenja, genotip, starost, zagađenje okoline, uzročnici bolesti, insekti i dr.) (Ilić, 2009). Stoga, pravovremeni pronalazak strane vrste štetnog agensa, odnosno insekta može doprinijeti u definiranju i poduzimanju kvalitetnih mjera zaštite šuma hrasta. Entomološki kompleks hrasta kitnjaka obuhvaća velik broj vrsta, a posebno mjesto predstavljaju insekti listova u koje spada i hrastova mrežasta stjenica (Zúbrik i dr., 2013).
Sjevernoamerički rod Corythucha (Heteroptera: Tingidae) obuhvaća 49 vrsta mrežastih stjenica autohtonih za područje Sjeverne Amerike (Mutun i dr., 2009; Hrašovec i dr., 2013). Prethodno je na područje Europe unesena platanina mrežasta stjenica Corythucha ciliata (Linnaeus) (Maceljski, 1986). Unosom platana u parkove 80-tih godina prošloga stoljeća unesena je na područje Bosne i Hercegovine (Gavrilović, 1980). Hrastova mrežasta stjenica (Corythucha arcuata (Say) je unesena na područje Italije 2000. godine (Bernardinelli i Zandigiacomo, 2000). U idućem razdoblju proširila se u skoro sve dijelove Europe (Mutun, 2003; Csoka i dr., 2013). U Hrvatskoj je otkrivena 2013. godine (Hrašovec i dr., 2013).

Cilj ovoga rada je bilo utvrđivanje prisutnosti hrastove mrežaste stjenice morfološkim putem na istraživanim lokalitetima.

\footnotetext{
1 prof. dr. sc. Mirza Dautbašić, e-mail: mirzad@bih.net.ba, 'prof. dr. sc. Osman Mujezinović, e-mail: osmansfs@yahoo.com, Šumarski fakultet Univerziteta u Sarajevu, Katedra za zaštitu šuma, urbanog zelenila i lovnog gospodarenja, Zagrebačka 20, 71000 Sarajevo, Bosna i Hercegovina

${ }^{2}$ Dr. sc. Kenan Zahirović, JP Šumsko-privredno društvo Zeničko-dobojskog kantona d.o.o Zavidovići, Alije lzetbegovića 25, 72220 Zavidovići, Bosna i Hercegovina, e-mail: zahirovic_kenan@yahoo.com

${ }^{3}$ prof. dr. sc. Josip Margaletić, Šumarski fakultet Sveučilišta u Zagrebu, Zavod za zaštitu šuma i lovstvo, Svetošimunska cesta 25, 10000 Zagreb, Hrvatska, e-mail: josip.margaletic@sumfak.hr
} 

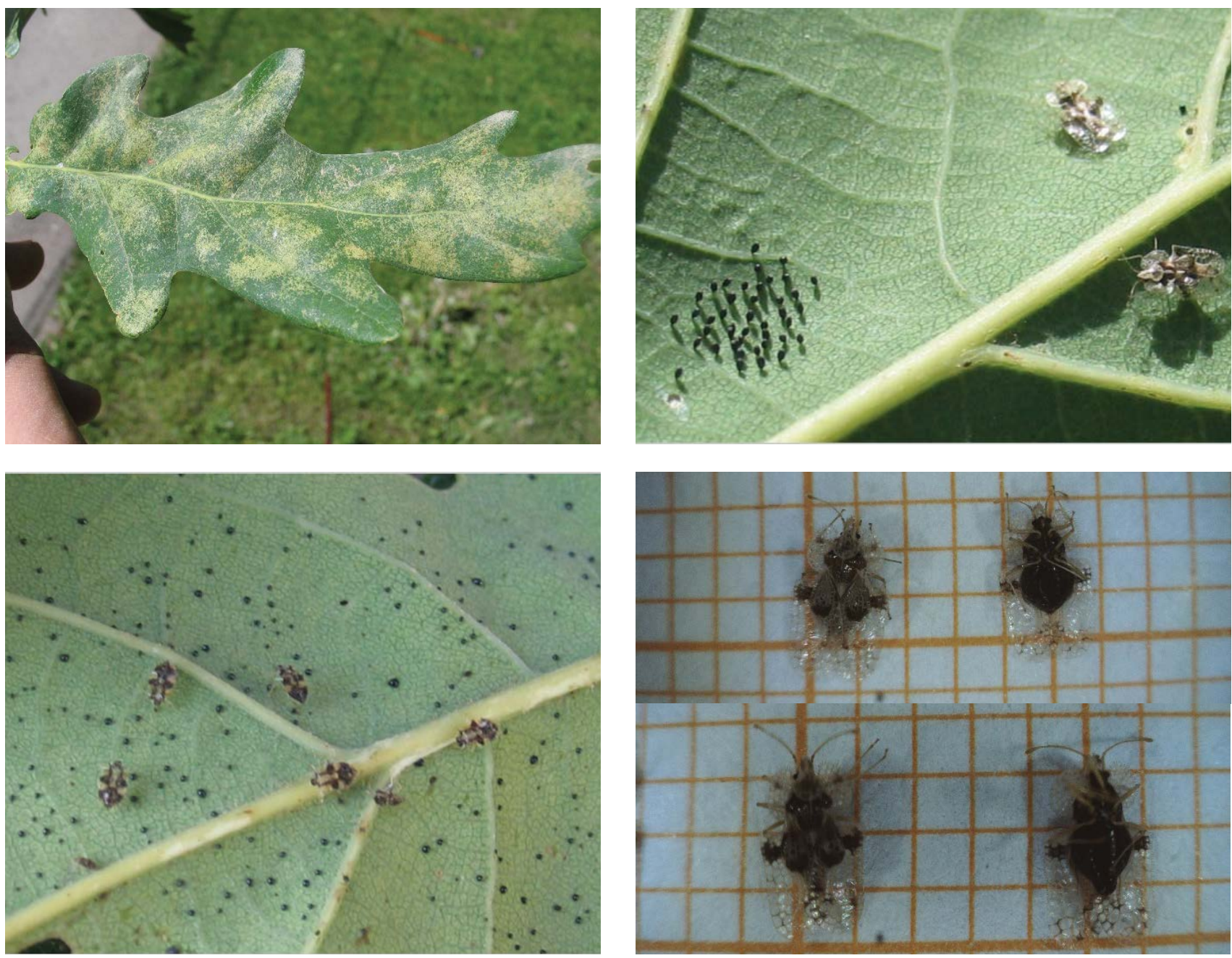

Slika 1, 2, 3 i 4. Kloroza lista hrasta kitnjaka; jajašca i imaga; nimfe; i imaga štetnika (ženka-leđno i trbušno; mužjak-trbušno) Corythucha arcuata Picture 1, 2, 3 and 4. Leaf chlorosis of sessile oak, eggs and adults, nymphs; and adults of pest (female-dorsal and ventral view; male-ventral view) Corythucha arcuata

\section{MATERIJAL I METODE MATERIALS AND METHODS}

Rekognosticiranjem terena u kolovozu 2017. godine u Bosni i Hercegovini na stablima hrasta kitnjaka Quercus petraea (Mattuschka) Lieblein, utvrđena je prisutnost kloroze listova, prisutnost ekskremenata, jajašaca, nimfi i imaga. Istraživanja su provedena na ukupno dva lokaliteta na području centralne Bosne (tablica 1). Jajašca, nimfe i imaga s lokaliteta istraživanja sakupljeni su i pohranjeni u $75 \%$ etanol, radi kasnijih morfoloških analiza. Determinacija štetnika izvršena je u laboratoriju Katedre za zaštitu šuma i urbanog zelenila Šumarskog fakulteta Univerziteta u Sarajevu. Ista je provedena po ključu na temelju (Forster i dr., 2005), (na osnovi građe i oblika vratnog štita, oblika ovipozitora kod ženke), na temelju razvojnih stadija imaga, nimfi i jajašaca. Razvojni stadiji insekta fotografirani su prenosnim mikroskopom SVP DM540 i digitalnim fotoaparatom Canon PowerShot G5. Nakon provedenih morfoloških analiza, primjerci štetnika pohranjeni su u hladnjaku. Ovim istraživanjem nije proučavana biologija ove vrste.

Tablica 1. Lokaliteti prvog nalaza hrastove mrežaste stjenice u Bosni i Hercegovini

Table 1. Localities of first record of oak lace bug in Bosnia and Herzegovina

$\begin{array}{lcc}\text { Datum - Date } & \text { Lokalitet - Locality } & \text { Koordinate - Coordinates } \\ \text { 09.08.2017. } & \text { Ivančevo } & 44^{\circ} 12^{\prime} 30^{\prime \prime} \mathrm{N} ; 18^{\circ} 25^{\prime} 27^{\prime \prime} \mathrm{E} \\ \text { 10.08.2017. } & \text { Vijaka } & 44^{\circ} 12^{\prime} 21^{\prime \prime} \mathrm{N} ; 18^{\circ} 25^{\prime} 47^{\prime \prime} \mathrm{E}\end{array}$

\section{Rezultati}

Hrastova mrežasta stjenica prvi je puta otkrivena u Bosni i Hercegovini na hrastu kitnjaku 9. 8. 2017. godine na lokalitetu Ivančevo, općina Vareš. Daljnjim pregledom štetnik je utvrđen na lokalitetu Vijaka.

Na napadnutim listovima je bila vidljiva kloroza listova, posebice na mlađim stablima (slika 1). Na donjoj strani lista nađena su jajašaca (slika 2), zatim nimfe (slika 3 ) i imaga (slika 4). Nije utvrđeno sušenje listova. 


\section{RASPRAVA I ZAKLJUČCI}

\section{DISCUSSION AND CONCLUSIONS}

Hrastova mrežasta stjenica može se smatrati stranom vrstom na području Bosne i Hercegovine. Smatramo da je štetnik raširen na područje Bosne i Hercegovine iz susjedne Hrvatske, i to najprije u područje sjeveroistočne Bosne, a kasnije i južnije. S obzirom na to da je štetnik otkriven na području središnje Bosne može se pretpostaviti da je prisutan na cijelom području sjeverne Bosne, ali za to su potrebne dodatne potvrde. Prisutnost štetnika nije utvrđena uzorkovanjem lisnog materijala južnije od mjesta nalazišta (južni dijelovi planine Zvijezda). Stoga se trenutno ovo nalazište može smatrati kao najjužnija tačka rasprostranjenja hrastove mrežaste stjenice u Bosni i Hercegovini. Kako je rasprostranjenje hrasta kitnjaka u Bosni i Hercegovini vezano uglavnom za sjeverne dijelove Bosne (Matić i dr., 1971), može se smatrati da je ovaj novi štetnik prisutan u navrijednijim sastojinama ove vrste drveća u Bosni i Hercegovini. Štete od hrastove mrežaste stjenice manifestiraju se u sušenju i preranom opadanju listova (Hrašovec i dr., 2013). Prema Poljaković-Pajnik i dr. (2015) štete se ogledaju u smanjenju intenziteta fotosinteze napadnutih listova, što ukazuje na pojačan stres napadnutih biljaka. Imajući u vidu ovu činjenicu, kao i informacije da su sastojine hrasta kitnjaka na području sjeverne Bosne posebno ugrožene od hrastove imele (Loranthus europeus) (Ilić, 2009), ali i drugih štetnih agenasa (Siwecki i Ufnalski, 1998), možemo pretpostaviti da će ova nova vrsta imati značajan utjecaj na pogoršanje zdravstvenog stanja ove vrste drveća. Istraživanja ovog štetnika, a ponajprije interdisciplinarnog karaktera, u budućnosti će trebati dati odgovore na pitanja puteva njihovog širenja, štetnog djelovanja, odnosa s drugim vrstama organizama u šumskim ekosustavima i mjera zaštite hrastovih šuma, kao i drugih domaćina.

Na osnovi prvog nalaza hrastove mrežaste stjenice može se zaključiti sljedeće:

- Štetnik je u Bosnu i Hercegovinu došao najvjerojatnije prirodnim rasprostranjenjem, nakon što je 2013. godine otkriven na području Hrvatske;

- Pronađena su jajašca, nimfe i imaga hrastove mrežaste stjenice na listovima hrasta kitnjaka;

- Na dvije lokacije utvrđeno je 45 nimfi i 21 imago štetnika,

- Potrebna su dodatna istraživanja biologije, štetnosti i širenja štetnika na stablima hrasta kitnjaka te ostalim domaćinima u Bosni i Hercegovini.

\section{LITERATURA}

\section{REFERENCES}

- Bernardinelli, I., Zandigiacomo, P. (2000): Prima segnalazione di Corythucha arcuata (Say) (Heteroptera, Tingidae) in Europa. Informatore Fitopatologico, 50: 47-49.

- Csóka, G., Hirka, A., Somlyai, M. (2013): A tölgy csipkéspoloska (Corythucha arcuata Say, 1832 - Hemiptera, Tingidae) elsô észlelése Magyarországon. Növényvédelem, 49(7): 293-296.

- Forster, B., Giacalone, I., Moretti, M., Dioli, P., Wermelinger, B. (2005): Die Amerikanishe Eichennetzwaanze Corythucha arcuata (Say) (Heteroptera, Tingidae) hat die Südschweitz erreicht. Mitteilungen der Schweizerischen Entomologischen Gessellschaft Bulletin de la Societe Entomologue Suisse, 78: 317-323

- Gavrilović, D. (1980): Prva pojava i rasprostranjenost mrezaste stjenice platana (Corythucha ciliata (Say)) u Bosni i Hercegovini. Narodni šumar.

- Hrašovec, B., Posarić, D., Lukić, I., Pernek, M. (2013): Prvi nalaz hrastove mrežaste stjenice Corythucha arcuata u Hrvatskoj. Šumarski list, 9-10: 499-503.

- Ilić, N. (2009): Decline of sessile oak [Quercus petraea (Mattuschka) Lieblein] and occurrence of the mistletoe Loranthus europaeus Jacq. on mountain Motajica. Works of Faculty of Forestry. University of Sarajevo. No. 1. str. 22-33.

- Maceljski, M. (1986): Current status of Corythucha ciliata in Europe. EPPO Bulletin, 16: 621-624.

- Matić, V., Drinić, P., Stefanović, V., Ćirić, M., Beus, V., Bozalo, G., Golić, S., Hamzić, U., Marković, Lj., Petrović, M., Subotić, M., Talović, N., Travar, J. (1971): Stanje šuma u Bosni i Hercegovini (prema inventuri šuma na velikim površinama 1964-1968). Šumarski fakultet i Institut za šumarstvo Sarajevo. Posebno izdanje br. 7.

- Mutun, S. (2003): First report of the oak lace bug, Corythucha arcuata (Say, 1832) (Heteroptera: Tingidae) from Bolu, Turkey. Israel Journal of Zoology, 49(4): 323-324.

- Mutun, S., Ceyhan, Z., Sözen, C. (2009): Invasion by the oak lace bug, Corythucha arcuata (Say) (Heteroptera: Tingidae), in Turkey. Turkish Journal of Zoology, 49(4): 323-324.

- Poljaković-Pajnik, L., Drekić, M., Pilipović, A., Nikolić, N., Pap, P., Vasić, V., Marković, M. (2015): Pojava velikih šteta od Corythucha arcuata (Say) (Heteroptera: Tingidae) u šumama hrasta u Vojvodini. XIII savetovanje o zaštiti bilja. Zbornik radova. str. 63.

- Siwecki, R., Ufnalski, K. (1998): Review of oak stand decline with special reference to the role of drought in Poland. Europ. J. For. Path. 28. str. 99-112.

- Zúbrik, M., Kunca, A., Csóka, G. (2013): Insects and Diseases Damaging Trees of Europe. N.A.P. Éditions. A colour atlas. str. $1-535$.

\section{Summary}

This research is first record of oak lace bug (Corythuca arcuata) in the municipality of Vareš, Bosnia and Herzegovina on two localities. It was found eggs, nymphs and adult insects of oak lace bug on the leaves of sessile oak. Since this is a foreign and potentially invasive species, its spread throughout the territory of Bosnia and Herzegovina can be expected.

KEY WORDS: sessile oak, oak lace bug, alien species, Vareš, Bosnia and Herzegovina. 